\title{
Heroes and Holidays: The Status of Diversity Initiatives at Liberal Arts College Libraries
}

\section{Julie Gilbert}

\begin{abstract}
Studies about diversity initiatives in academic libraries have primarily focused on large research libraries. But what kinds of diversity work occur at smaller libraries? This study examines the status of diversity initiatives, especially those aimed at students, at national liberal arts college libraries. Results from a survey of library directors reveal that, while diversity programming happens informally at most libraries, and while diversity is valued by library directors, diversity work has not been prioritized at the organizational level in any systematic manner.
\end{abstract}

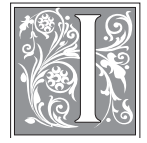

n 2000, Mark D. Winston and Haipeng Li investigated the status of diversity programs in liberal arts college libraries. After a review of the literature, they concluded that such initiatives have occurred primarily at large research university libraries and are almost nonexistent at liberal arts college libraries. ${ }^{1}$ A review of the literature published since 2000 indicates that very little has been written about diversity initiatives specific to liberal arts college libraries in the intervening years. ${ }^{2}$ This lack of information raises several questions, which form the basis of this study:

- What, if anything, are liberal arts college libraries doing to support diversity, specifically programming and services for students?

- What kinds of barriers might impact the ability of liberal arts college libraries to promote diversity?

- Finally, do liberal arts college libraries believe it is important to promote diversity and why?

This study sheds light on the kinds of diversity programming at liberal arts college libraries by analyzing results of a national survey of library directors. While the study touches on issues such as workplace climate assessment, staff recruitment and retention, and managing diversity work, it primarily investigates the kinds of diversity initiatives libraries undertake that are directed at their students. The study also examines the role an institutional commitment to diversity plays in the library's own diversity work. The study considers barriers preventing libraries from achieving the full potential of their diversity programming and concludes with reflections provided by library directors about the role of the liberal arts college library in promoting diversity.

Julie Gilbert is Associate Professor in Folke Bernadotte Memorial Library at Gustavus Adolphus College; e-mail:jgilber2@gustavus.edu. (C) 2016 Julie Gilbert, Attribution-NonCommercial (http://creativecommons. org/licenses/by-nc/3.0/) CC BY-NC. 


\section{Literature Review}

The American Library Association (ALA) identifies diversity as "a fundamental value of the association and its members" ${ }^{\prime 3}$ and includes diversity as one of the association's key action areas. ${ }^{4}$ The Association of College \& Research Libraries (ACRL) expresses a similar commitment to diversity in the Diversity Standards: Cultural Competency for Academic Libraries. The standards, which were developed by ACRL's Racial and Ethnic Diversity Committee, outline eleven areas related to diversity work within academic libraries: cultural awareness of self and others; cross-cultural knowledge and skills; organizational and professional values; development of collections, programs, and services; service delivery; language diversity; workforce diversity; organizational dynamics; cross-cultural leadership; professional education and continuous learning; research. ${ }^{5}$

Association of Research Libraries (ARL) member libraries reflect a commitment to diversity as documented in SPEC Kit 319: Diversity Plans and Programs. ${ }^{6}$ Of particular note is the degree to which diversity work has been formalized within libraries' operating structures. According to the publication's summary survey, 86 percent of plans included in the kit list specific goals and strategies related to diversity and 57 percent list organization responsibility and accountability. ${ }^{7}$ Specific approaches include implementing diversity committees, hiring multicultural librarian positions, intentionally developing programming for specific groups of users, and establishing relationships with diversity officers on campus.

Several key themes and priorities emerge in the broader literature related to diversity initiatives in academic libraries, which in turn shape this study. While not a comprehensive list of diversity work being conducted within academic libraries, these priorities reflect many of those outlined by Diversity Standards: Cultural Competency for Academic Libraries and SPEC Kit 319: Diversity Plans and Programs: assessing diversity initiatives, recruiting and retaining a diverse workforce, and providing outreach services and programming that meet the needs of diverse groups of users. The literature also considers best practices in how diversity work is managed.

Much of the literature on diversity assessment involves investigating the library's current climate. Drawing on workplace diversity literature, Paula Smith develops standards for libraries using tools such as climate assessments to measure how well they demonstrate characteristics of culturally conscious organizations. ${ }^{8}$ According to Johnnieque B. (Johnnie) Love, a workplace climate assessment should be conducted prior to implementing diversity initiatives, as it allows the library to understand its current situation, identify future growth areas, and provide standards against which to measure performance. ${ }^{9}$ Molly Royse, Tiffani Conner, and Tamara Miller outline how the University of Tennessee Libraries' Diversity Committee used a climate assessment to determine the libraries' readiness to develop a diversity plan, indicating that the study's methodology can be replicated at other institutions. ${ }^{10}$ Furthermore, workplace climate assessments are an ongoing process, as demonstrated by Zheng Ye (Lan) Yang and Brenda White, who describe how ongoing workplace assessments continue to shape diversity priorities at Texas A\&M University Libraries. ${ }^{11}$ Librarians at Indiana University-Purdue University Indianapolis (IUPUI) find that collections, resources, staff, and programming should continually be assessed to measure the impact of diversity initiatives. ${ }^{12}$

Multiple approaches to recruit and retain a diverse library workforce are evident within the profession and well documented within the literature. Teresa Y. Neely outlines a variety of programs at the national level to recruit, retain, and promote librarians of diverse backgrounds, including ALA's Spectrum Initiative. ${ }^{13}$ Retention efforts at the Pennsylvania University Libraries, as discussed by Linda R. Musser, include mentoring 
library employees of diverse backgrounds, creating networking opportunities, encouraging professional development, and creating a welcoming climate. ${ }^{14}$ Ricardo Andrade and Alexandra Rivera describe how data from a climate assessment at the University of Arizona Libraries led to the creation of diversity competencies that are used during the hiring process for librarians. ${ }^{15}$ Janice Simmons-Welburn illuminates the role that Diversity Dialogue Groups have in fostering communication and understanding among an increasingly multicultural library workforce. ${ }^{16}$ Additional examples for recruiting librarians of diverse backgrounds include forming connections with students currently enrolled in library science programs ${ }_{1}^{17}$ creating library internships for undergraduate of diverse backgrounds, ${ }^{18}$ and developing summer programs to introduce high school students to library science. ${ }^{19}$

When developing outreach services and diversity programming, academic libraries will be most successful when they define diversity broadly and work directly with diverse populations to identify needs. Anne T. Swizer discusses approaches undertaken at Oakland University's Kresge Library to meet the unique needs of a variety of groups, including collaboration with campus partners, individual research appointments, book clubs, and events. ${ }^{20}$ Librarians at Indiana University-Purdue University Indianapolis (IUPUI) demonstrate how creating an undergraduate diversity scholar program led to the scholars themselves generating a wealth of additional programming ideas, including book clubs, displays, repositories, connections with campus partners, events, and orientations..$^{21}$ Justina O. Osa encourages libraries first to identify underserved populations and then gather information from those populations to develop initiatives. ${ }^{22}$ When working with international students in particular, John Hickok advocates learning as much as possible about students' previous library experiences to best guide developing appropriate services. ${ }^{23}$

The question remains: who is best positioned to manage various aspects of diversity work within libraries? Winston indicates the work originates with library managers, who shoulder responsibility for being familiar with the literature on diversity within the profession; library managers are also best positioned to motivate staff and set informed diversity priorities. ${ }^{24}$ Roberto G. Trujillo and David C. Weber concur, stating that, while all library staff are responsible for prioritizing diversity, senior library administrators are best positioned to influence the direction of the work..$^{25}$ Deloice G. Holliday outlines the opportunities afforded by a multicultural outreach librarian position, ${ }^{26}$ an approach further expanded by Lori Mestre, whose book, Librarians Serving Diverse Populations: Challenges and Opportunities, details the benefits a multicultural librarian position offers both patrons and the library itself. ${ }^{27}$

As noted above, literature focused specifically on diversity initiatives at liberal arts college libraries remains sparse. A 1999 study conducted by Li outlines specific barriers facing liberal arts college libraries, such as lack of staff time and financial resources; he further notes that careful planning can provide for successful diversity programs. ${ }^{28}$ Winston and Li survey liberal arts college library directors, focusing specifically on diversity efforts involving recruiting and retaining staff, workplace environment, collections, and services, with a special emphasis on the role of library diversity committees and college diversity officers. ${ }^{29}$ In 2005 , Li conducted a follow-up study of 166 liberal arts college libraries; his findings suggest that diversity programs at liberal arts college libraries can flourish provided the library engages in careful long-term planning. ${ }^{30}$

This study seeks to investigate the degree to which diversity programming and services for students are pursued at national liberal arts college libraries, as well as how such work is managed. The study also considers additional diversity work conducted by libraries, namely assessment methods, recruiting and retention of employees with diverse backgrounds, and management of diversity. Furthermore, the study investigates 
the role the larger institution plays in library diversity work. With its focus on national liberal arts college libraries, this study helps to fill a sizable gap in the literature.

\section{Methodology}

To study diversity initiatives in liberal arts college libraries, the author developed a 22-question survey to send to college library directors (see appendix A for the survey instrument). Questions were based on diversity areas outlined by Winston and $\mathrm{Li}^{31}$ and included an emphasis on the existence and role of a library diversity committee and/ or a college diversity officer. Questions were also drawn from the broader literature on diversity initiatives at academic libraries, including several priorities identified in SPEC Kit 319: Diversity Plans and Programs and ACRL's Diversity Standards: Cultural Competency for Academic Libraries.

In January and February of 2013, the author generated an e-mail list of college library directors at all institutions listed as National Liberal Arts Colleges by U.S. News $\mathcal{E}$ World Reports, thereby creating a sample of libraries similar to each other in terms of their focus on undergraduate education. Out of 252 national liberal arts colleges included by U.S. News E World Reports, 224 received survey invitations. The author's own institution was excluded, as well as a handful of institutions that did not provide contact information for any staff. There were also a few instances where one person directed two (or more) libraries and thus received only one survey invitation. Following the methodology used by Winston and Li, who argued that directors had the best view about diversity within their own libraries, ${ }^{32}$ the survey was sent only to library directors. The survey was sent via SurveyMonkey in April 2013, with a two-week window to complete. The survey closed with a response rate of 24.6 percent.

\section{Profile of Survey Population}

The survey sample is generally representative of national liberal arts college libraries. Slightly more than one-third $(34.5 \%)$ are located in urban settings, slightly more than one-fourth $(27.3 \%)$ are in suburban settings, and the rest $(38.2 \%)$ are located in rural settings. A little more than one-third (36.4\%) are in the northeastern or eastern United

\begin{tabular}{|l|l|}
\hline \multicolumn{2}{|c|}{$\begin{array}{c}\text { TABLE 1 } \\
\text { Employee Profile (Percentages) } \\
(\mathbf{n}=56)\end{array}$} \\
\hline Librarians & 29.1 \\
\hline $0-5$ & 50.9 \\
\hline $6-10$ & 10.9 \\
\hline $11-15$ & 5.5 \\
\hline $16-20$ & 3.6 \\
\hline More than 20 & 20.0 \\
\hline Total library staff (including librarians) \\
\hline $0-5$ & 20.0 \\
\hline $6-10$ & 21.8 \\
\hline $11-15$ & 9.1 \\
\hline $16-20$ & 9.1 \\
\hline $20-25$ & 20.0 \\
\hline More than 25
\end{tabular}

States, less than one-third (29.1\%) are in the southern United States, one in five $(20.0 \%)$ are in the Midwest, and slightly less than one in ten $(9.1 \%)$ are in the western United States. (An additional three libraries [5.5\%] self-identified as being in the mid-Atlantic states.) Nearly nine in ten $(89.1 \%)$ have a total student body of 3,000 or less. More than half of all respondents (58.2\%) are at institutions where the percentage of traditionally underrepresented students is less than 20 percent. Nearly one in five (18.2\%) are at institutions where the percentage is between 21 and 30 percent.

The libraries themselves have small staffs. Less than one-third (29.1\%) report that the number of FTE librarians is five or less; half (50.9\%) indicate the number is between 6 and 10 (see table 1).

Almost three-fourths of survey respondents $(72.7 \%)$ report that the percentage of 
employees from traditionally underrepresented groups is 10 percent or less. Nearly one in five (18.2\%) indicate the percentage is between 11 and 20 percent.

\section{Findings}

\section{Diversity Programming and Services}

Two-thirds of survey respondents $(66.0 \%)$ intentionally undertake programming designed to promote diversity. A small contingent (1.9\%) are in the process of starting diversity programming, while others (5.7\%) are planning to start efforts in the coming year. While this means that nearly three-quarters (73.6\%) of liberal arts college libraries are involved with diversity initiatives at some stage, it is worth noting that slightly more than one-fourth of survey respondents (26.4\%) are not pursuing any initiatives related to diversity at all. Cross-tabulation indicates that geographical location of the school has a slight impact on whether or not a library undertakes diversity programming: 81.3 percent of schools in the southern United States undertake such programs, compared to 70.0 percent of Midwestern schools, 63.2 percent of northeastern/eastern schools and 60.0 percent of western schools.

The liberal arts college libraries that pursue diversity initiatives undertake a wide variety of activities (see figure 1). The most common activities are creating permanent or rotating displays highlighting diversity (50.9\%); providing equipment for people with disabilities, such as a Kurzweil machine or software (50.9\%); developing collections focused on diversity (50.9\%); and collaborating with relevant offices or committees on campus, such as a campus diversity center (49.1\%). Libraries also provide outreach to diverse students or student groups (41.8\%) and prepare print or online guides highlighting library resources related to diverse populations $(41.8 \%)$. Slightly more than one-third of respondents (36.4\%) offer workshops for specific groups of students, such as ELL or first-generation college students; the same percentage of respondents (36.4\%) offers diversity programming, such as a speaker series focusing on diversity issues. Less common activities include offering print or online tutorials for specific groups of students (18.2\%); providing materials for users with disabilities, such as books in Braille (14.5\%); signs addressing the needs of diverse users, such as bilingual signs (14.5\%); coordinating book clubs focusing on diversity issues (14.5\%); and providing marketing aimed specifically at users from diverse backgrounds $(12.7 \%)$.

In open-ended comments, survey respondents mentioned additional diversityrelated activities, such as making study areas accommodating for students with physical

\section{FIGURE 1}

\section{Diversity Related Activities for Patrons $($ Percentages $)(\mathrm{n}=38)$}

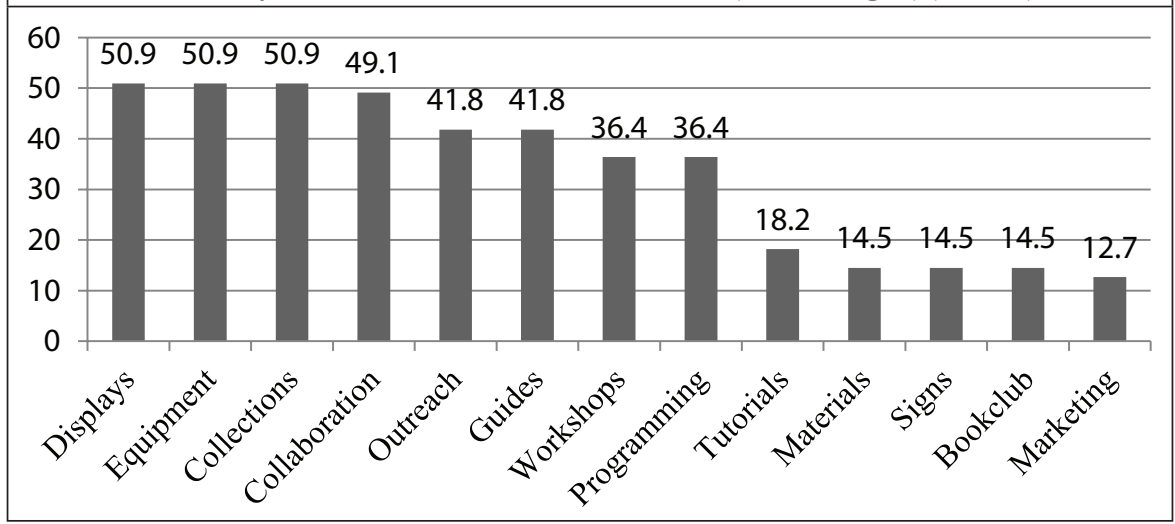


disabilities, introducing a paging system to ensure physical collections are accessible by everyone, and offering gender-neutral restrooms. Survey respondents who undertake diversity initiatives pursue four activities on average, although this should also be considered in light of the fact that more than one-fourth $(26.4 \%)$ of libraries are not conducting any initiatives at all, as discussed above.

Cross-tabulation shows that the library's setting impacts whether or not a library will offer online tutorials or research guides for specific groups of users, such as ELL students or first-generation college students (see table 2). Nearly one-third of libraries in urban settings $(31.6 \%)$ and more than one-fourth of libraries in suburban settings $(26.7 \%)$ offer this service, compared to none of the schools in rural settings $(0.0 \%)$. These differences are strongly statistically significant. Setting also impacts whether or not a library will provide print or web guides to library resources highlighting diverse populations. Well over half of libraries in urban settings (57.9\%) offer these services, as well as nearly half of libraries in suburban settings (46.7\%). By contrast, libraries in rural settings are much less likely than other libraries to offer this service (only $23.8 \%$ provide these types of guides); these differences are also statistically significant.

\begin{tabular}{|c|c|c|c|}
\hline \multicolumn{4}{|c|}{$\begin{array}{c}\text { TABLE } 2 \\
\text { Diversity Initiatives by Setting }(\text { Percentages })(\mathrm{n}=\mathbf{3 8})\end{array}$} \\
\hline & Urban & Suburban & Rural \\
\hline \multicolumn{4}{|c|}{$\begin{array}{l}\text { Online Tutorials } \\
p<.021\end{array}$} \\
\hline - $\quad$ Yes & 31.6 & 26.7 & 0.0 \\
\hline - $\quad$ No & 68.4 & 73.3 & 100.0 \\
\hline \multicolumn{4}{|c|}{$\begin{array}{l}\text { Research Guides } \\
p<.084\end{array}$} \\
\hline - $\quad$ Yes & 57.9 & 46.7 & 23.8 \\
\hline - $\quad$ No & 42.1 & 53.3 & 76.2 \\
\hline \multicolumn{4}{|l|}{$\begin{array}{l}\text { Outreach } \\
p<.104\end{array}$} \\
\hline - $\quad$ Yes & 52.6 & 53.3 & 23.8 \\
\hline - $\quad$ No & 47.4 & 46.7 & 76.2 \\
\hline \multicolumn{4}{|c|}{$\begin{array}{l}\text { Collection Development } \\
p<.166\end{array}$} \\
\hline - $\quad$ Yes & 68.4 & 40.0 & 42.9 \\
\hline $\begin{array}{ll} & \text { No } \\
\end{array}$ & 31.6 & 60.0 & 42.9 \\
\hline \multicolumn{4}{|c|}{$\begin{array}{l}\text { Book Club } \\
p<.181\end{array}$} \\
\hline - $\quad$ Yes & 15.8 & 26.7 & 4.8 \\
\hline - $\quad$ No & 84.2 & 73.3 & 95.2 \\
\hline \multicolumn{4}{|c|}{$\begin{array}{l}\text { Programming } \\
p<.192\end{array}$} \\
\hline - $\quad$ Yes & 36.8 & 53.3 & 23.8 \\
\hline - $\quad$ No & 63.2 & 46.7 & 76.2 \\
\hline
\end{tabular}


Although the findings are slightly less statistically significant, setting also influences the likelihood of a library to undertake outreach to diverse students or student groups on campus, to have collection development priorities focused on diversity, to sponsor a book club with a focus on diversity, and to offer programming related to diversity.

\section{Assessment of Diversity Programming}

Of the thirty-eight libraries conducting diversity programming, only nine $(23.7 \%)$ have assessed the success of their library's diversity activities. Seven of the nine indicate they use a combination of focus groups and surveys to gain feedback on their programming, often as part of a broader end-of-year library survey. Survey respondents share additional insights gleaned from assessment efforts:

- "There is a growing need for diversity discussions on our campus. Students are willing to be a part of helping us develop programs and services in the library."

- "The best programs are ones that reduce barriers to entry for all."

- "Visual cues are very important. We are continuing to work on making the visual spaces represent our commitment to diversity through posters, signage and displays."

- "We are making progress but should continue our efforts."

\section{Additional Diversity Activities}

Survey respondents indicate a strong commitment to hiring practices that recruit librarians of diverse backgrounds $(67.3 \%)$ and student workers of diverse backgrounds $(67.3 \%)$ as well as recruiting staff of diverse backgrounds (58.2\%) (see figure 2). Only a handful of respondents $(7.3 \%)$ report having a retention program for librarians and staff of diverse backgrounds. Slightly more than half of respondents $(52.7 \%)$ conduct diversity training for library employees, while less than one in five respondents $(18.2 \%)$ have conducted a workplace diversity climate assessment. Cross-tabulations reveal no factors that significantly impact a library's likelihood to undertake any of these activities.

\section{Managing Diversity}

In general, liberal arts college libraries have not prioritized diversity at the organizational level. Slightly less than one-third of survey respondents $(32.1 \%)$ report that their library currently has a stated commitment to diversity, articulated in official library documents such as the mission statement (see table 3). Nearly three-quarters

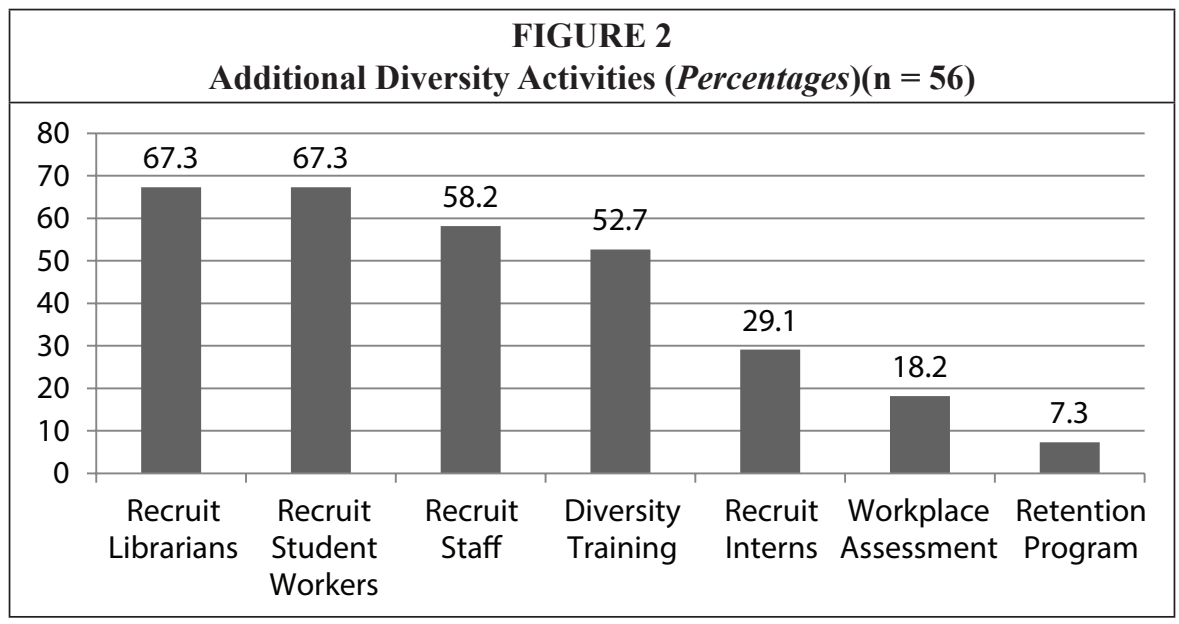




\begin{tabular}{|l|c|c|c|c|}
\hline \multicolumn{5}{|c|}{ TABLE 3 } \\
Organizational Commitment to Diversity (Percentages)(n= 56) \\
\hline & Yes & No & $\begin{array}{c}\text { Currently } \\
\text { Developing }\end{array}$ & $\begin{array}{c}\text { Not } \\
\text { Sure }\end{array}$ \\
\hline $\begin{array}{l}\text { A stated commitment to diversity, articulated in } \\
\text { official library documents, such as the mission } \\
\text { statement }\end{array}$ & 32.1 & 58.5 & 5.7 & 3.8 \\
\hline An official plan for fostering diversity & 18.9 & 71.7 & 5.7 & 3.8 \\
\hline $\begin{array}{l}\text { A librarian position charged (either full or part } \\
\text { time) with promoting diversity }\end{array}$ & 9.4 & 88.7 & 1.9 & 0.0 \\
\hline $\begin{array}{l}\text { A support staff position charged (either full or } \\
\text { part time) with promoting diversity }\end{array}$ & 5.8 & 92.3 & 1.9 & 0.0 \\
\hline A diversity committee within the library & 5.7 & 90.6 & 3.8 & 0.0 \\
\hline
\end{tabular}

of respondents $(71.7 \%)$ report no official plan, while a few libraries (5.7\%) are currently developing a diversity plan. Less than one in ten respondents $(9.4 \%)$ have a librarian position charged with promoting diversity, and only a few libraries $(5.8 \%)$ have a staff position charged with diversity activities. Similarly, very few libraries (5.7\%) report the presence of a diversity committee within their organizational structure. Crosstabulation with independent variables, such as setting, location, staff size, and percent of employees from underrepresented groups reveals that no significant factors predict the likelihood of a library to have any of these features.

\section{Diversity at the Institutional Level}

Libraries in the study are almost unanimously situated within institutions that prioritize diversity at the institutional level. Almost all survey respondents (94.5\%) agree that promoting or fostering diversity is a stated priority at their institution, articulated in official documents such as the mission statement or strategic plans, with nearly three-fourths of respondents (70.4\%) strongly agreeing. Well over half of respondents $(58.2 \%)$ report that their institution has a college diversity or affirmative action officer. Of those who do have an institutional diversity or affirmative action officer $(n=32)$, nearly one-third of survey respondents $(31.3 \%)$ meet with the officer several times a year, while nearly one-third (31.3\%) meet with the officer less than once a year, and more than one-third (37.5\%) say they never meet with the officer.

Meeting with the diversity or affirmative action officer provides an opportunity for library directors to discuss several issues related to diversity, including hiring, collaboration on programming, and information sharing. Respondents who do meet with the officer $(n=20)$ provide specific examples in open-ended questions:

- " "[We meet with the officer] when we hire and when we have a problem."

- "Diversity is addressed by more than one administrative area and we meet with representatives of all the offices from time to time: Intercultural Center, International Student Program, Disability Services, Campus Ministry, etc. Meetings may be just informational, raising awareness of services, to learning about specific strategies we may adopt, to offering joint programming."

- "We are involved in planning some activities, and help plan in many efforts that affect the entire campus."

- "All college employees, including those in the library, are required to attend a diversity/affirmative action workshop conducted by the officer once every year."

- "The Library Director and the officer work together to promote diverse activities." 


\section{Barriers to Pursuing Diversity Programming}

Survey respondents cite lack of time as the biggest barrier to pursuing diversity-related activities, with half of all respondents $(50.9 \%)$ indicating this is a problem. Lack of funding emerges as the second largest barrier, with a sizable minority $(43.6 \%)$ identifying this as a barrier. Slightly less than one-fourth of respondents $(23.6 \%)$ say that they have not encountered any barriers to diversity-related activities. Respondents overwhelmingly indicate that lack of employee interest and lack of interest from library users are not barriers, with only one in ten respondents $(9.1 \%)$ saying each of these is a barrier. Nearly one in five respondents $(18.2 \%)$ reports that lack of institutional support is a barrier. No significant differences were found by institutional setting, geographic location, number of student FTE, percentage of traditionally underrepresented students, number of FTE librarians, number of FTE staff, or percentage of traditionally underrepresented library employees.

Through open-ended questions, respondents also indicate a number of additional barriers they have encountered at their institutions. Many responses speak to the ways a library's unique context and setting impact diversity activities; a few also raise concerns over the fact that library employees simply have not thought about diversity in any kind of systematic way, especially as it relates to their work:

- "We are very understaffed and do not offer much in the way of programming beyond course-related instruction and library orientations for new students. We also have not found our non-course-related workshops to be well attended."

- "We are a very small library, too small to have a dedicated position or even a committee. Even so, there is a lot of diversity among the library faculty. The college has many diversity-focused groups which the library works with."

- "We do not know what is effective."

- "Lack of knowledge on best practices for promoting diversity, especially those pertaining to libraries. Coordinating and sustaining cooperation across campus divisions has been difficult."

- "Lack of clarity about exactly what to do probably plays a role as well."

- "I'm not aware that we've encountered any barriers to pursuing diversityrelated initiatives per se."

- "I suspect it hasn't occurred to most library staff that there is any need for /value generated from diversity efforts. That is, diversity isn't resisted, it's merely not part of the library staff's world view regarding their work lives."

\section{Importance of Promoting Diversity}

Study findings have illuminated the degree to which survey respondents pursue diversity initiatives, as well as shed light on some of the barriers libraries face. A third goal of the study was to determine why national liberal arts college libraries would promote diversity, if they did at all. Survey respondents who conducted diversity initiatives aimed at students were invited to comment on reasons why they undertook those activities. The reasons fell into three broad yet overlapping categories: a mandate from the institution, a response to diversity on campus, and a sense that this commitment is in line with the mission of libraries in general.

As observed earlier, most libraries are at institutions that have a stated commitment to diversity. This commitment has guided the work of several survey respondents:

- "College has diversity in its overall mission. Library is dedicated to promoting diversity."

- "Diversity is a part of the collegewide strategic priorities."

- "It's consistent with the values of the school."

- "We have an institutionwide commitment to diversity, and the library supports 
the college's mission. It is important for us to do whatever we can to promote understanding of different points of view, ideas and experiences."

Several respondents conduct diversity initiatives as a response to diversity on their campuses:

- "Our campus is diverse and we want the library to be relevant and necessary to all students."

- "We have increasingly diverse students and need to reflect that in our outreach, services, collections, and student workers."

- "Because our campus is so diverse in its student population and education."

- A number of respondents indicate they pursue diversity initiatives because to do so aligns with the basic philosophies of librarianship:

- "Because we want all students to feel as if the Libraries are their places to be, learn, and to become inducted into the scholarly community."

- "We want to be known as an inclusive library, supportive of all members of our community."

- "To be inclusive, as well as to inform dominant populations about others in our society."

- $\quad$ "Because we are committed to serving our users and respecting tolerance and creating a community which is inclusive."

- "To be relevant and useful to our entire community, and to assure that all users will encounter an array of materials and services that are broad and expansive."

- "To do so is aligned with our understanding of the underlying philosophies of librarianship."

Finally, respondents comment on what role, if any, that the liberal arts college library plays in promoting diversity. Most respondents agree that the library could and should be a leader in providing diversity initiatives on campus. (Only one respondent says that the library plays "a minor role" in promoting diversity.)

Many spoke to the position of the library on campus as key to shaping its role in promoting diversity:

- "The library can be an important component in promoting diversity. It is the one place on campus that holds access to all the thought and scholarship regardless of discipline."

- "The library epitomizes the goals of a diverse campus - a space where all are welcome, collections present the breadth of perspectives, and programming and services celebrate inclusion."

- $\quad$ "Since the Library is used by everyone, we have a special obligation and opportunity to be inclusive. We can be a model in both our behaviors and our resources. Libraries have a long tradition of protecting freedom of expression, which calls us to be responsible for creating an environment in which different voices are not only heard but acknowledged."

Respondents also point out the unique role the liberal arts plays in prioritizing and promoting diversity:

- "When you think about a liberal arts education, the goal is to expose students to an array of education subjects, promoting the arts, and community service. Liberal arts education always promoted a diverse platform for educating future generations of students."

- "A liberal arts college library should welcome a wide range of patrons; its collections should reflect a diversity of perspectives. It can provide a 'neutral' meeting ground for people from different backgrounds and holding different beliefs."

- "The liberal arts college promotes diversity of ideas and therefore should actively promote other types of diversity." 
- "Just as our liberal arts curriculum is interdisciplinary, so should be our students, faculty and staff. This is the real world-diverse and amazing!"

\section{Discussion}

When measured against diversity practices identified in the literature, diversity initiatives at national liberal arts college libraries are a mixed bag. Three-quarters of libraries do undertake multiple ways of promoting diversity aimed at students, although these tend to be approaches that do not grow out of a formal diversity plan. Creating displays, providing equipment for people with disabilities, and collaborating with relevant campus groups are among the most frequently pursued diversity initiatives. Libraries also conduct outreach to diverse students and prepare print or online guides highlighting diverse collections. It is important to remember, however, that more than one-quarter of libraries are not undertaking any kind of diversity programming whatsoever. Whereas some libraries are moving beyond what is known as the "heroes and holidays" stage in the education literature, where diversity is marked mainly through displays during various holidays and events such as Black History Month, ${ }^{33}$ other libraries appear to have done next to nothing in terms of intentionally incorporating a core value of the profession.

Very few libraries undertake any kind of assessment, whether in terms of assessing specific programming or through conducting a workplace climate assessment. National liberal arts college libraries should consider using a workplace climate assessment to better understand attitudes toward diversity among employees. A workplace climate assessment would also help libraries identify priorities related to diversity, thus helping to develop the kinds of structures, such as committees and plans, that result in systematic, comprehensive approaches to diversity.

While two-thirds of libraries pursue strategies to recruit librarians and staff of diverse backgrounds, and most libraries provide diversity training for employees, few have developed retention programs. The findings further indicate that most libraries in the sample do not employ a significant percentage of librarians of diverse backgrounds. This suggests that libraries study and implement recruitment programs, as well as consider how hiring practices might be improved to result in hiring more librarians of diverse backgrounds. While recruiting and retaining a diverse workforce does not guarantee that a library will be more intentional about pursuing diversity initiatives that target students, a more diverse workforce does provide broader experiences and outlooks from which a library can operate.

By and large, national liberal arts colleges do not manage diversity work well in comparison with libraries at research institutions. As the findings demonstrate, diversity initiatives within the libraries do not stem from formal structures within the libraries themselves. While a handful of libraries have or are creating diversity plans, the majority has not codified support of diversity at the organizational level. By using tools such as a workplace climate assessment, as mentioned above, and examples from other libraries, such as those presented in Spec Kit 319, national liberal arts college libraries can begin to develop diversity plans that clearly lay out priorities and responsibilities.

The libraries represented in the study are situated at institutions that have made diversity a stated priority at the organizational level. Many institutions also provide support in terms of a diversity or affirmative action officer. This kind of institutional commitment to diversity raises the question: what kinds of support can libraries draw from their home institutions in terms of supporting diversity work and management within the library? Can libraries leverage resources from their parent institutions to pursue diversity in a more comprehensive manner?

Undertaking diversity work is not easy, however, and the barriers to promoting diversity are significant. Respondents report that lack of time and lack of funding are 
primary challenges. Most respondents agree that library employees and patrons are interested in the library promoting diversity, indicating at least an initial level of support for diversity initiatives. The library's setting has an effect on at least some level of programming; libraries in urban settings are more likely to offer services such as such as online tutorials, research guides, book clubs, and programming, compared to libraries in suburban and rural settings.

In light of the significant barriers facing libraries, do survey respondents still think it is important to pursue diversity initiatives? Absolutely. Many directors articulate a belief that promoting diversity is core to the ideals of librarianship. They touch on values of open access to everyone, serving the needs of a particular community, reflecting the experiences of a diverse world, and highlighting the stories and experiences of those who have traditionally been overlooked and ignored.

While national liberal arts college libraries do not have the staffing or budgets typically associated with larger libraries, there is little reason to believe smaller libraries cannot implement some of the successful approaches outlined in the existing literature. What would it look like for a smaller library to conduct a workplace climate assessment, study the results, and begin conversations to develop a diversity plan? How might an individual library scale and implement a successful program that began at a larger institution? What lessons can be learned from existing literature, including the ACRL standards?

National liberal arts college libraries would benefit from simply sharing practices and approaches with each other. Many survey respondents said they want to know more about what other libraries are doing to shape individual library diversity programs, as expressed by this representative comment: "There is clearly a role for libraries to play in diversity, but I am uncertain how libraries have successfully supported and promoted diversity beyond the 'open access for all' model." As libraries continue to pursue diversity, they should consider venues for sharing their experiences with a broader audience.

The literature is primed for a growth in case studies from national liberal arts college libraries that highlight diversity initiatives, as well as the challenges and opportunities provided by their unique context. Additional future research also stems from the limits of the current study; new studies might expand the survey population beyond deans and directors. Future studies might also investigate the barriers faced by libraries in greater depth, such as lack of training or institutional support. Finally, there is a growing body of literature that directly surveys students of diverse backgrounds and their perceptions of libraries; such studies could easily be replicated in national liberal arts college libraries. ${ }^{34}$

\section{Conclusion}

Budget and staff constraints affect libraries in countless ways. In the most recent Ithaka S+R US Library Survey, nearly 90 percent of directors at all academic libraries felt constrained by budget issues; nearly 50 percent also state that staffing issues are a concern. ${ }^{35}$ These barriers are reflected in national liberal arts college library directors' concerns about implementing diversity work. In light of these concerns, it might be easy to let diversity work slide or let it peak at the heroes and holidays stage. Yet the library profession and survey respondents themselves continually affirm that diversity is a central component of librarianship. In light of this charge, rather than focus on barriers, national liberal arts college libraries should ask themselves, what is the cost of not making diversity a central component of the college library? The work starts by considering the needs of the library's community and continues by implementing a systematic, comprehensive approach to diversity within all areas of the library's work. 


\section{Appendix A}

1. Please indicate whether or not your library has the following:

A stated commitment to diversity, articulated in official library documents, such as the mission statement

$\square$ Yes $\square$ No $\square$ Currently Developing $\square$ Not Sure

An official plan for fostering diversity, including goals and objectives

$\square$ Yes $\square$ No $\square$ Currently Developing $\square$ Not Sure

A diversity committee consisting of library employees

$\square$ Yes $\square$ No $\square$ Currently Developing $\square$ Not Sure

A librarian position charged (either full- or part-time) with promoting diversity

$\square$ Yes $\square$ No $\square$ Currently Developing $\square$ Not Sure

A support staff position (either full- or part-time) with promoting diversity

$\square$ Yes $\square$ No $\square$ Currently Developing $\square$ Not Sure

2. At my library, we intentionally undertake programming designed to promote diversity or provide outreach to diverse populations, regardless of whether or not we have an official diversity plan.

$\square$ Yes $\square$ No $\square$ Currently Developing $\square$ Planning to Start Within a Year

3. What kinds of diversity-related activities do you do in your library? (choose as many as applicable)

$\square$ Signs addressing the needs of diverse users (for example, bilingual signs)

Displays highlighting diversity issues (permanent or rotating)

Access to equipment for people with disabilities, like a Kurzweil or magnifying machine

Materials for users with disabilities, such as books in Braille

$\square$ Online tutorials or research guides for specific groups of users (ELL, first-generation college students, and so on)

Workshops or instruction sessions for specific groups of users

Web or print research guides highlighting library resources related to diverse populations

Collection development priorities related to diversity issues

$\square$ Programming such as a speaker series, film series, panel discussions, and the like related to diversity issues

$\square$ Library-sponsored book clubs or reading groups focusing on diversity issues

$\square$ Library marketing aimed at users from diverse backgrounds

Outreach to diverse students or student groups on campus

Collaboration with relevant offices or committees on campus, such as a campus Diversity Center

$\square$ Other

4. What are the top one or two reasons your library undertakes these diversityrelated activities? (open-ended)

5. Have you assessed the success or impact of your library's diversity activities in any way?

$\square$ Yes $\square$ No $\square$ Not Sure

6. What techniques have you used to assess your library's diversity-related activities? (open-ended) 
7. What are some of the insights you learned from your assessment? (open-ended)

8. What are some of the barriers your library has encountered to pursuing diversityrelated activities? (choose as many as applicable)

$\begin{array}{ll}\square \text { Lack of employee time } & \square \text { Lack of employee interest } \\ \square \text { Lack of institutional support } & \square \text { Funding constraints }\end{array}$

$\square$ Lack of interest/response from library users

$\square$ We have not encountered any barriers $\square$ Other

9. At my library, we undertake the following additional diversity-related activities (check all that apply):

$\square$ Recruiting librarians of diverse backgrounds

$\square$ Recruiting staff of diverse backgrounds

$\square$ Recruiting library interns of diverse backgrounds

$\square$ Recruiting student workers of diverse backgrounds

$\square$ Retention program for librarians and/or staff of diverse backgrounds

$\square$ Retention program for library interns and/or student workers of diverse backgrounds

- Training for library employees, such as workshops to create a diversity-supportive workplace

$\square$ Conducting a workplace climate assessment

$\square$ We have not undertaken any additional diversity-related activities

$\square$ Other (open ended)

10.Promoting or fostering diversity is a stated priority at my institution, articulated in official institutional documents (such as mission statement, strategic plan, and the like).

$\square$ Strongly agree $\square$ Agree somewhat $\square$ Neutral/Not Sure

$\square$ Disagree somewhat $\square$ Strongly Disagree

11. My institution has a college diversity/affirmative action officer.

$\square$ Yes $\square$ No $\square$ Not Sure

12. The college diversity/affirmative action officer meets with the library

$\square$ More than once a month $\square$ Several times a year $\square$ Less than once a year

Never

13. In what ways, if at all, does the library work with the college diversity/affirmative action officer? (open-ended)

14. In your opinion, what role, if any, does the liberal arts college library play in promoting diversity? (open-ended)

15. Is there anything else you would like to share about liberal arts college libraries and diversity? (open-ended)

16. My institutional setting is
$\square$ Urban
$\square$ Suburban
Rural

17. My institution is geographically located in

$\square$ Northeastern/Eastern United States $\square$ Southern United States

$\square$ Midwest United States $\square$ Western United States $\square$ Other 
18. The number of student FTE at my institution is
$\square$ Less than 1,000
口 1,000-2,000
$\square$ 2,001-3,000
? 3,001-4,000
ㄴ,001-5,000
More than 5,000

19. The percentage of traditionally underrepresented students at my institution is
口 $0 \%-10 \%$
- $11 \%-20 \%$
- $21 \%-30 \%$
口 $31 \%-40 \%$
- $41 \%-50 \%$
口 $51 \%-60 \%$ - $61 \%-70 \%$
口 71\%-80\%
$81 \%-90 \%$
口 $91 \%-100 \%$

20.The number of FTE librarians at my library is
口 0-5 a 6-10
口 11-15
口 16-20
More than 20

21. The number of FTE staff at my library is
$\square 0-5$
a 6-10
口 11-15
口 16-20
21-25 More than 25

22. The percentage of traditionally underrepresented employees (librarians and staff) in my library is
口 $0 \%-10 \%$
- $11 \%-20 \%$
$21 \%-30 \%$
ㄱ $31 \%-40 \%$
$41 \%-50 \%$
口 $51 \%-60 \%$ 口 $61 \%-70 \%$
口 $71 \%-80 \%$
$81 \%-90 \%$
口 91\%-100\%

\section{Notes}

1. Mark D. Winston and Haipeng Li, "Managing Diversity in Liberal Arts College Libraries," College \& Research Libraries 61, no. 3 (2000): 205-15.

2. Mark Winston, "Diversity: The Research and the Lack of Progress," New Library World 109, no. 3 (2008): 130-49.

3. "Diversity," American Library Association, available online at www.ala.org/advocacy/diversity [accessed 13 August 2015].

4. "Key Action Areas," American Library Association, available online at www.ala.org/aboutala/ missionpriorities/keyactionareas [accessed 13 August 2015].

5. "Diversity Standards: Cultural Competency for Academic Libraries (2012)," Association of College $\mathcal{E}$ Research Libraries, available online at www.ala.org/acrl/standards/diversity [accessed 13 August 2015].

6. Charlene Maxey-Harris and Toni Anaya, Spec Kit 319: Diversity Plans and Programs (Washington, D.C.: Association of Research Libraries, 2010).

7. Ibid, 22.

8. Paula Smith, "Culturally Conscious Organizations: A Conceptual Framework," portal: Libraries and the Academy 8, no. 2 (2008): 141-55.

9. Johnnieque B. (Johnnie) Love, “The Assessment of Diversity Initiatives in Academic Libraries," Journal of Library Administration 33, no. 1/2 (2001): 73-103.

10. Molly Royse, Tiffani Conner, and Tamara Miller, "Charting a Course for Diversity: An Experience in Climate Assessment," portal: Libraries and the Academy, 6, no. 1 (2006): 23-45.

11. Zheng Ye (Lan) Yang and Brenda White, "The Evaluation of a Diversity Program at an Academic Library," Library Philosophy and Practice (2007), available online at http://digitalcommons.unl.edu/libphilprac/149 [accessed 13 August 2015].

12. Kathleen A. Hanna, Mindy M. Cooper, and Robin A. Crumrin, Diversity Programming and Outreach for Academic Libraries (Oxford: Chandos Publishing, 2011), 96.

13. Teresa Y. Neely, "Diversity Initiatives and Programs: The National Approach," in Managing Multiculturalism and Diversity in the Library, ed. Mark Winston (New York: The Haworth Press, 1999), 123-44.

14. Linda R. Musser, "Effective Retention Strategies for Diverse Employees," in Diversity Now: People, Collections, and Services in Academic Libraries, eds. Teresa Y. Neely and Kuang-Hwei (Janet) Lee-Smeltzer (New York: The Haworth Press, 2001), 63-72.

15. Ricardo Andrade and Alexandra Rivera, "Developing a Diversity-Competent Workforce: The UA Libraries' Experience," Journal of Library Administration 51, no. 7/8 (2011): 692-727.

16. Janice Simmons-Welburn, "Diversity Dialogue Groups: A Model for Enhancing Work Place Diversity," in Managing Multiculturalism and Diversity in the Library, ed. Mark Winston (New York: The Haworth Press, 1999), 111-21.

17. Jametoria Burton and W. Michael Havener, "Diversity and Recruiting Practices: How 
LIS Schools and Practitioners Work Together," in Achieving Diversity: A How-To-Do-It Manual for Librarians, eds. Barbara I. Dewey and Loretta Parham (New York: Neal-Schuman, 2006), 76-92.

18. Hanna, Cooper, and Crumrin, Diversity Programming and Outreach, 25-44.

19. Jessica Kayongo, LeRoy LaFleur, and Ira Revels, "Reaching High School Students: Sowing the Seeds of Librarianship," in Achieving Diversity: A How-To-Do-It Manual for Librarians, eds. Barbara I. Dewey and Loretta Parham (New York: Neal-Schuman, 2006), 102-13.

20. Anne Switzer, "Redefining Diversity: Creating an Inclusive Academic Library through Diversity Initiatives," College E Undergraduate Libraries 15, no. 3 (2008): 280-300.

21. Hanna, Cooper, and Crumrin, Diversity Programming and Outreach, 45-70.

22. Justina O. Osa, "Tips and Practices for Quality Library User Services in a Diverse Environment," in Achieving Diversity: A How-To-Do-It Manual for Librarians, eds. Barbara I. Dewey and Loretta Parham (New York: Neal-Schuman, 2006), 137-51.

23. John Hickok, "Knowing Their Background First: Understanding Prior Library Experiences of International Students," in International Students and Academic Libraries, eds. Pamela A. Jackson and Patrick Sullivan (Chicago: Association of College and Research Libraries, 2011), 1-17. $58-63$

24. Mark Winston, “Managing Diversity,” Library Leadership E Management 24, no. 3 (2010):

25. Roberto G. Trujillo and David C. Weber, "Academic Library Response to Cultural Diversity: A Position Paper for the 1990s," Journal of Academic Librarianship 17, no. 3 (1991): 157-61.

26. Deloice G. Holliday, "Developing Approaches for Working with Diverse User Populations," in Achieving Diversity: A How-To-Do-It Manual for Librarians, eds. Barbara I. Dewey and Loretta Parham (New York: Neal-Schuman, 2006), 126-36.

27. Lori Mestre, Librarians Serving Diverse Populations: Challenges \& Opportunities (Chicago: Association of College \& Research Libraries, 2010).

28. Haipeng Li, "Diversity in the Library: What Could Happen at the Institutional Level," Journal of Library Administration 27, no. 1/2 (1999): 145-56.

29. Winston and Li, "Managing Diversity."

30. Haipeng Li, "Liberal Arts College Libraries and the Management of Diversity," Chinese Librarianship: An International Electronic Journal, no. 20 (2005), available online at www.iclc.us/cliej/ cl20li.htm [accessed 13 August 2015].

31. Winston and Li, "Managing Diversity."

32. Ibid.

33. Paul C. Gorski, "Stages of Multicultural Curriculum Transformation," Multicultural Curriculum Reform, available online at www.edchange.org/multicultural/curriculum/steps.html [accessed 13 August 2015].

34. For example, Ethelene Whitmire, "The Campus Racial Climate and Undergraduates' Perceptions of the Academic Library," portal: Libraries and the Academy 4, no. 3 (2004): 363-78; Denice Adkins and Lisa Hussey, "The Library in the Lives of Latino College Students," Library Quarterly 76, no, 4 (2006): 456-80; Sharon Elteto, "Is the Library a 'Welcoming Space'?: An Urban Academic Library and Diverse Student Experiences," portal: Libraries and the Academy 8, no. 3 (2008): 325-37.

35. Matthew P. Long and Roger C. Schonfeld, Ithaka S+R US Library Survey 2013, available online at www.sr.ithaka.org/sites/default/files/reports/SR_LibraryReport_20140310_0.pdf, 21 [accessed 13 August 2015]. 